\title{
Unilateral Quadripartite Composition of Pectoral Major Muscle: Anatomical Description and Clinical Implications
}

\author{
Composición Unilateral Cuadripartita del Músculo Pectoral Mayor: \\ Descripción Anatómica e Implicancias Clínicas
}

Ruchi Dhuria; Vandana Mehta; Hitendra Loh; Jyoti Arora; Sanchita Roy; Rajesh Suri \& Gayatri Rath

DHURIA, R.; MEHTA, V.; LOH, H.; ARORA, J.; ROY, S. SURI, R. \& RATH, G. Unilateral quadripartite composition of pectoral major muscle: Anatomical description and clinical implications. Int. J. Morphol., 27(4):1213-1216, 2009.

SUMMARY: A unilateral anomalous disposition of the muscular slips of pectoralis major was observed in an adult male cadaver during routine gross anatomy teaching session. The pectoralis major muscle displayed unusual configuration and comprised of four parts delineated by three intramuscular clefts. Further, the sternocostal part was found to divide into two fasciculi. The origin and insertion of pectoralis major muscle was as usual and unremarkable. Interestingly, the innervation of the muscle was observed to bear an important variation. The clavicular and sternocostal slips of pectoralis major muscle received a direct branch from the lateral cord of brachial plexus in addition to its usual innervation from the lateral and medial pectoral nerves. The multiplicity of innervation of pectoralis major as encountered in the present study would presumably augment its suitability for its use in reconstructive procedures. An additional anomalous attachment of the pectoralis minor muscle was also observed emanating from the second rib, apart from the usual third, fourth and fifth ribs. These variants of the pectoral muscles may also have implications in biomechanical studies, as they may alter the kinematics.

KEY WORDS: Pectoralis major muscle; Muscle; Anomaly; Innervation.

\section{INTRODUCTION}

The pectoralis major muscle is a thick triangular fan shaped muscle of the anterior chest wall. It usually arises from anterior surface of the medial two thirds of the clavicle, half breadth of anterior surface of sternum upto sixth costal cartilage, first to sixth costal cartilages and from the aponeurosis of external oblique muscle of abdomen. These three parts, the clavicular, sternocostal and aponeurotic head combine together and form a fan shaped muscle. Finally the muscle fibres form a tendon and converge upwards and laterally towards their insertion into the lateral lip of bicipital groove of humerus. The pectoralis major is a powerful adductor and medial rotator of the arm (Sinnatamby, 2006). The sternocostal part is the chief adductor and the clavicular fibres assist in flexion. When the upper limb is fixed in abduction,the pectoralis major acts as a useful accessory muscle of inspiration drawing the ribs upwards towards the humerus. The pectoralis major is supplied by the medial and lateral pectoral nerves (Stranding, 2008).

After a thorough review of literature, it was found that the common variations of pectoralis major muscle are

Anatomy, VMMC \& Safdarjung Hospital, New Delhi, India. absence of one of the slips or unilateral absence of the muscle (Bonastre, 2002), (Mosconi, 2003). We present a unique unilateral composition of pectoralis major muscle with an unusual innervation. The pectoralis major was found with quadripartite composition with an additional nerve, derived from the lateral cord of the brachial plexus. It was seen to supply the clavicular slip and the upper sternocostal slip. The pectoralis minor muscle had an additional slip arising from the second rib on the same side. Multiple nerve supply of muscle assumes relevance while performing muscle transfers. A sound anatomical knowledge of pectoral musculature is imperative for interpretation of MRI and for reconstructive surgeons who may find it useful to utilize these supernumerary slips during surgeries.

\section{CASE REPORT}

Variation in the pectoral musculature of right side was noted during routine dissection in an adult male cadaver. 
The pectoralis major muscle of the anterior chest wall was observed with quadripartite composition (Fig. 1). The origin and the insertion of this muscle were found as usual. It was divided into four muscular slips by three intramuscular septa. The first slip was observed to originate from the clavicle, while the second and third slip had a sternocostal origin. Interestingly, the fourth slip had an aponeurotic origin. Further, the first and second muscular slips fused together to form a common muscle belly. The third and fourth muscular slips were seen to merge with this common belly successively. The three intramuscular clefts between four muscular slips measured $8.5 \mathrm{~cm}, 11 \mathrm{~cm}$ and $9.3 \mathrm{~cm}$ respectively in length. The average gap between the slips was $3 \mathrm{~mm}$. The innervation to the pectoralis major muscle was from the lateral and medial pectoral nerves as usual. The unique feature of the present study was an additional twig from lateral cord innervating the first and second slips of the muscle. The pectoralis minor muscle also displayed an additional attachment to the second rib along with the usual attachment (Fig. 2). However, its innervation and insertion were normal. The external appearance of anterior thoracic wall did not reveal any obvious abnormality.

Table I. Intramuscular clefts in pectoralis major muscle.

\begin{tabular}{lccc}
\hline $\begin{array}{l}\text { Position of } \\
\text { intramuscular cleft }\end{array}$ & $\begin{array}{c}\text { Length of } \\
\text { cleft }(\mathrm{cm})\end{array}$ & $\begin{array}{c}\text { Distance between } \\
\text { medial end of cleft } \\
\text { and midsternal line } \\
(\mathrm{cm})\end{array}$ & $\begin{array}{c}\text { Distance between } \\
\text { lateral end of cleft } \\
\text { and insertion of } \\
\text { PM }(\mathrm{cm})\end{array}$ \\
\hline Superior cleft & 8.5 & 5.8 & 6.8 \\
Intermediate cleft & 9.3 & 6.6 & 4.3 \\
Inferior cleft & 11.0 & 10.8 & 5.4 \\
\hline
\end{tabular}

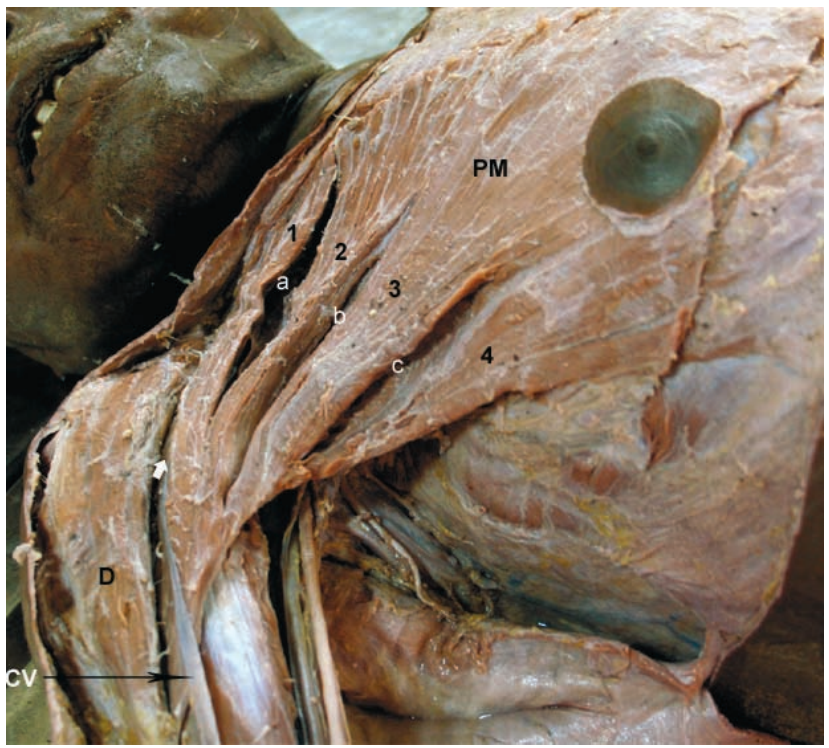

Fig. 1. Photograph showing the pectoralis major muscular slips and intramuscular clefts. PM. Pectoralis major muscle; 1. Clavicular slip of pectorais major muscle; 2. Upper sternocostal slip of pectoralis major muscle; 3 . Lower sternocostal slip of pectoralis major muscle; 4. Aponeurotic slip of pectoralis major; D. Deltoid muscle; CV. Cephalic vein; a. Superior intramuscular cleft; b. Intermediate intramuscular cleft; c. Inferior intramuscular cleft; Deltopectoral groove (white arrow).

Fig. 2. Photograph showing nerve supply of Pectoralis Major muscle. C. Clavicle; PM. Pectoralis major muscle; Pm. Pectoralis minor

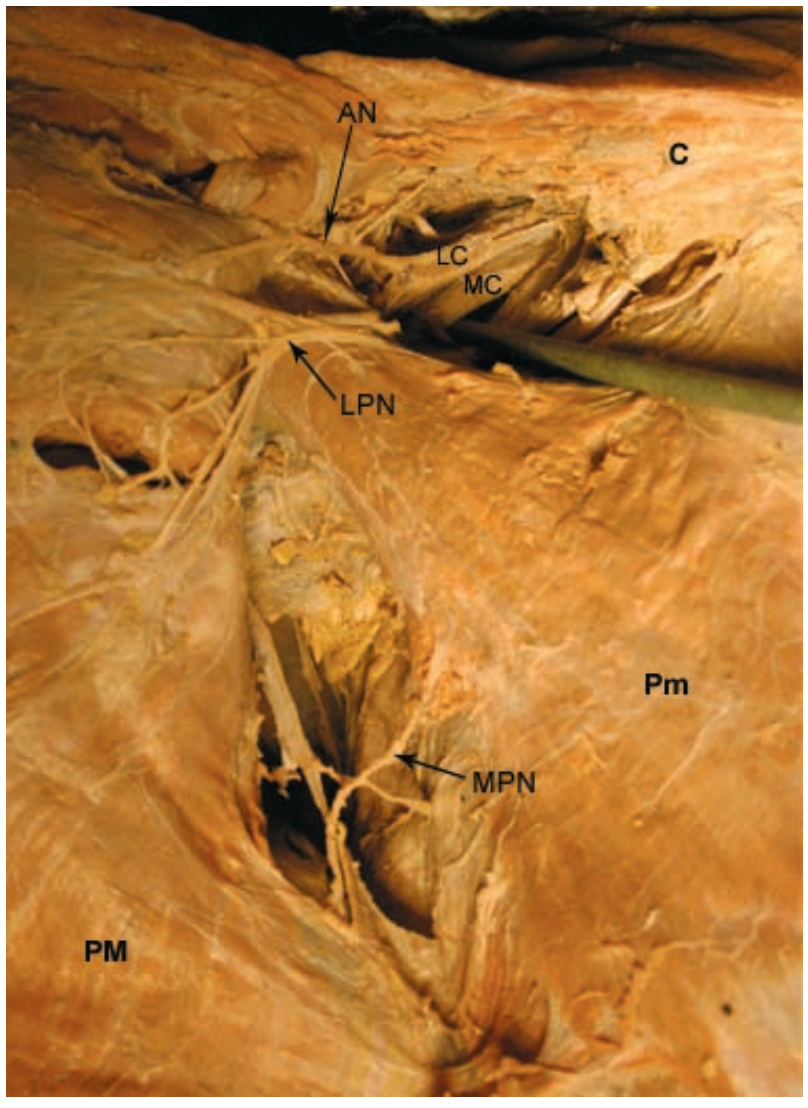
muescle; LC. Lateral cord of brachial plexus; MC. Medial cord of brachial plexus; MPN. Medial pectoral nerve; LPN. Lateral pectoral nerve; AN. Additional nerve arising from lateral cord of brachial plexus. 


\section{DISCUSSION}

Anomalous pectoral musculature has been usually reported earlier in literature (Standring, 2005). Our case is distinct from previous reports although malformation of pectoral musculature has been reported by several investigators. Recently, a prominent cleft separating the sternocostal and clavicular portions of pectoralis major was observed (Soni et al., 2008). The fibers of PM were partially fused with deltoid and resulting obliteration in deltopectoral groove. Unilateral four headed pectoralis major muscle with an accessory head was observed (Hammad \& Mohammed, 2006). Bilateral partial absence of clavicular head of pectoralis major with $2.5 \mathrm{~cm}$ gap was found between the clavicular and sternocostal head (Goval et al., 2006). The sternocostal head is most commonly maldeveloped and when absent it is accompanied by hypertrophy of clavicular head. Thus the primitive muscle mass, giving rise to pectoral muscles, attaches to the clavicle first, then fans out and subsequently attaches to the sternum and ribs. When the developmental arrest is partial, the sternocostal fibers are more likely to be affected, sparing clavicular fibers (Mosconi \& Kamath, 2003). In the present study, pectoralis major had four muscular slips separated by three incomplete intramuscular clefts of variable length.

Embryologically, the pectoral musculature is derived from dorsal limb bud masses which arise from myoblasts that migrate out of last five cervical and first thoracic myotomes into developing limb buds during fifth week of development (Sweeney, 1998). Pectoral muscles develop from a primitive muscle mass constituting the upper limb, derived from the fifth to the seventh cervical myotomes, during the fifth week of intra-uterine life (Turgut et al., 2000). The pectoral muscles assume their final forms through a combination of migration, fusion and apoptosis of muscle cell precursors (Carlson et al., 2004).

In present study, the clefts observed between the pectoralis major muscle could be attributed to improper fusion of cervical myotomes destined to form pectoral pre-muscle mass.

Rajalakhsmi mentioned three pectoral nerves directly coming from the lateral cord of brachial plexus (Rajalakhsmi et al., 2008). The position of these three nerves supplying the pectoralis major muscle is important while performing pectoralis major island flap transfers to head and neck region through the gap in delto-pectoral groove (Corten, 2003). Similarly the additional nerves from the lateral cord of brachial plexus observed in the present study supplying first and second slips of pectoralis major could be safely utilized for the same purpose.
Another advantage attributed to the additional innervation is that the risk of post operative paralysis of pectoralis major muscle is minimized. The quadripartite composition presenting additional slips could also be used for post-mastectomy repairs.

The utility of pectoralis major in head and neck reconstructions is immense. The pectoralis major myocutaneous flap has been extensively used in head and neck and axillary reconstructive surgeries (Rajalakhsmi et al., 2008). The topographical relationship, rich vascularity and thickness of the muscle are attributes which enhance the suitability of pectoralis major as a good candidate for flap transfers to reconstructions.

We suggest that unique quadripartite composition of the pectoralis major in the present study makes it a reliable source for performing these muscle transfers. The additional innervations of the first and second slips derived from the lateral cord have not been described earlier to the best of knowledge. Definitely lack of knowledge of these neural variations makes them prone to accidental injuries and entrapment syndromes. (Das, 2005). The topography of the muscle and related nerves assume importance for surgeons to avoid intra-operative complications.

\section{CONCLUSION}

It is important to be familiar with the anatomic variations of pectoral musculature and to identify them early in order to achieve an appropriate dissection plane during surgery of chest wall. Such anatomical anomalies may prove to be advantageous for cosmetic augmentations during reconstructive surgery of breast where pectoralis major can be partly preserved because of additional nerve supply. Awareness of possibility of such anomalies is important for radiologists during interpretation of skiagrams. The additional nerve supply of pectoralis major may also be utilised for undertaking correction of facial palsy.

DHURIA, R.; MEHTA, V.; LOH, H.; ARORA, J.; ROY, S. SURI, R. \& RATH, G. Composición unilateral cuadripartita del músculo pectoral mayor. Descripcción anatómica e implicancias clínicas. Int. J. Morphol., 27(4):1213-1216, 2009.

RESUMEN: Una disposición anómala unilateral de los vientres musculares del músculo pectoral mayor se observó en un cadáver adulto de sexo masculino durante una clase de rutina de anatomía. El músculo pectoral mayor mostró una configuración inusual y presentaba cuatro partes delimitadas por tres depresiones intramusculares. Además, la parte esternocostal se encontraba dividdida en dos fascículos. El origen y la inserción del músculo 
pectoral mayor era normal. Curiosamente, la inervación de los músculos, presentaba una importante variación anatómica. Los fascículos clavicular y esternocostal del músculo pectoral mayor recibieron una rama directa del fascículo lateral del plexo braquial, además de su inervación normal de los nervios pectoral lateral y medial. La múltiple inervación del músculo pectoral mayor como se encuentró en el presente estudio, probablemente, haga aumentar su idoneidad para el uso en procedimientos reconstructivos. También se observó un fascículo adjunto anómalo adicional del músculo pectoral menor, que se originaba de la segunda costilla, además de su origen en la tercera, cuarta y quinta costillas. Estas variaciones de los músculos pectorales también puede tener implicancias en estudios biomecánicos, ya que probablemente alteran la cinemática.

PALABRAS CLAVE: Músculo pectoral mayor; Músculo; variación anatómica; Inervación.

\section{REFERENCES}

Bonastu, V.; Rodriguer-Niedenfuhr, M.; Choi, D. \& Saundo J. R. Coexistence of a pectoralis quartus muscle and an unusual axillary arch: case report and review. Clin. Anat., 15:366-70, 2002.

Carlson, B. M. Human embryology and developmental biology. Mosby, 2004. pp 224-5.

Corten, E. M. L.; Schellekens, P. P. A.; Bleys, R. L. A. W \& Kon, M. The nerve supply to the clavicular part of the pectoralis major muscle : An anatomical study and clinical application of the function-preserving pectoralis major island flap. Plastic. reconstr surg., 112 (4):969$75,2003$.

Das, S. \& Paul, S. Anamolous branching pattern of lateral cord of brachial plexus. Int. J. Morphol., 23(4):289-92, 2005.

Goval, N.; Harjeet \&Gupta M. Bilateral variant origin of pectoralis major. Nepal med college, 8(1):65-8, 2006.

Loukas, M.; Grabska, J.; Tubbs, R. S. \& Louis, R. G. Jr. An unusual union of intercostobrachial nerve and the medial pectoral nerve. Folia Morphologica (Warsz), 66 (4): 356-9, 2007.

Loukas, M.; Louis, R. G. Jr.; Fogg, Q. A.; Hallner, B. \& Gupta, A. A. An unusual innervation of pectoralis minor and major muscles from a branch of the intercostobrachial nerve. Clin. Anat., 19(4):347-9, 2006.
Mosconi, T. \& Kamath, S. bilateral asymmetric deficiency of the pectoralis major muscle. Clin. Anat., 16:346-9, 2003.

Rai, R.; Ranade, A. V.; Prabhu, L. V.; Pai, M. M. \& Nayak, S. R. Accessory lateral pectoral nerves supplying the pectoralis major. Romanian Journal of Morphology Embryology, 49 (4): 577-9, 2008.

Rasheed bari Hammed \& Adel mohammed. Unilateral four headed pectoralis major. McGill Journal of medicine, 9(1): 28-30, 2006.

Sinnatamby, C. S. Last's Anatomy, regional and applied. $11^{\text {th }}$ ed. Elsevier, Churchill livingstone. pp. 50, 2006.

Soni, S.; Rath, G.; Suri, R. \& Loh, H. Anamolous pectoral musculature. Anatomical science international, 83:3103, 2008.

Standring, S. Grays anatomy. $40^{\text {th }}$ ed. Elsevier Churchill Living Stone, 2008. pp. 808.

Sweeney, L. J. Basic concepts in embryology. McGraw-Hill, 1998. pp 136-138

Turgut, H.; Anil, A.; Peker, T. \& Barut, C. Insertion abnormality of bilateral pectoralis minimus. Surg. Radiol. Anat., 22:55-7, 2000.

\author{
Correspondence to: \\ Dr. Ruchi Dhuria \\ Senior resident \\ Department of Anatomy \\ Vardhman Mahavir Medical College and \\ Safadarjung Hospital \\ New Delhi \\ 110029 \\ INDIA
}

E-Mail- ruchidhuria22@yahoo.com

Received: 20-05-2009

Accepted: 30-10-2009 